•数据论文・

\title{
广西花坪SITE100样地甲虫标本照片数据集
}

\author{
李盼盼 ${ }^{1}$, 佟一杰 ${ }^{2,3}$, 曹浩宇 ${ }^{1}$, 容国森 ${ }^{1}$, 覃诗晴 ${ }^{1}$, 杨星科 2,4 , 王国全 ${ }^{1 *}$, 白明 ${ }^{(2,3 *}$
}

1. 广西大学农学院植物科学国家级实验教学示范中心, 南宁 $530004 ; 2$. 中国科学院动物研究所动物进化与系统学重点实验室, 北京 100101; 3. 中国科学院大学, 北京 100049; 4. 广东省科学院动物研究所, 广东省动物保护与资源利用重点实验室, 广东省野生动物保护与 利用公共实验室, 广州 510260

摘要: 通过在全球定点布设长期样地，定量评估昆虫多样性与环境之间的关系具有重要意义。“SITE100”国际大科学计划在 全球选定 100 个大样地, 每个样地统一选用罐诱法、马氏网法和飞行阻隔法三类采集装备, 从物种、形态和遗传多样性三个维 度探究全球昆虫多样性格局。花坪被选为全球 100 个大样地之一。本文的数据集为花坪样地 2020 年生长季期间的鞘翅目收样 结果, 历时7个月(2020.05.09-2020.11.23), 涵盖10个样点, 每个样点包括1套飞行阻隔器、1套马氏网和10个埋罐, 平均每周访 问全部样点 1 次。研究期间共采集甲虫 8,914 头, 被划分为 563 个形态种, 涵盖57个科。数据集包括四部分, 第一部分为各样点 每个采集装备每次收样所获得甲虫标本的集体照原图, 共计644张, 压缩后为照片1.zip; 第二部分为标注了形态种编号的甲 虫标本的集体照, 共计644张, 压缩后为照片2.zip; 第三部分为甲虫标本数量统计数据, 涵盖2020年5月2日至2020年11月23日 期间3种采集方式各日期采集甲虫的数量、采集样点的经纬度以及海拔信息，共 2 个文件，压缩后为数据1.zip; 第四部分为甲 虫标本高级阶元(科级或亚科级)鉴定信息，共计 2 个文件，压缩后为数据2.zip。该数据集除了可以用于与其他SITE100样地结 果进行联合分析之外, 还可用来比较不同栖境中甲虫的类群分布和形态差异, 部分类群的背面观图片为后续的几何形态学或 者形态学研究提供数据支持。该数据集还是对花坪甲虫多样性的首次定量评估, 对于丰富我国生物多样性本底数据和了解我 国南方昆虫区系的来源具有重要意义。

关键词: 形态多样性; 被动采集; 飞行阻隔法; 马氏网法; 罐诱法

数据库(集)基本信息简介

\begin{tabular}{ll} 
数据库(集)名称 & 广西花坪SITE100样地甲虫标本照片数据集 \\
作者 & 李盼盼, 佟一杰, 曹浩宇, 容国森, 覃诗晴, 杨星科, 王国全, 白明 \\
通迅作者 & 王国全(wangguoquan0@163.com), 白明(baim@ioz.ac.cn) \\
时间范围 & 2020年5月9日至11月23日 \\
地理区域 & 花坪, $109^{\circ} 47^{\prime} 07^{\prime \prime}-109^{\circ} 58^{\prime} 10^{\prime \prime} \mathrm{E}, 25^{\circ} 28^{\prime} 55^{\prime \prime}-25^{\circ} 39^{\prime} 15^{\prime \prime} \mathrm{N}$ \\
文件大小 & $6.32 \mathrm{~GB}$ \\
数据格式 & *.zip \\
数据链接 & https://www.scidb.cn/s/VVveuq \\
& http://doi.org/10.11922/sciencedb.00061 \\
& https://www.biodiversity-science.net/fileup/1005-0094/DATA/2021212.zip \\
数据库(集)组成 & 数据集包括1个压缩包, 共分为4个部分: (1)照片1.zip, 各样点每个装备每次收样所获得甲虫标本的集体照原图; (2)照片 \\
& 2.zip, 标注了形态种编号的甲虫标本的集体照; (3)数据1.zip, 甲虫标本数量统计数据, 涵盖2020年5月2日至11月23日3种采 \\
& 集方式各日期采集甲虫的数量、采集样点的经纬度以及海拔信息; (4)数据2.zip, 甲虫标本高级阶元(科级或亚科级)鉴定信息。 \\
\hline
\end{tabular}

李盼盼, 佟一杰, 曹浩宇, 容国森, 覃诗晴, 杨星科, 王国全, 白明 (2021) 广西花坪SITE100样地甲虫标本照片数据集. 生物多样性, 29, 1165-1169. doi: 10.17520/biods.2021212.

Li PP, Tong YJ, Cao HY, Rong GS, Qin SQ, Yang XK, Wang GQ, Bai M (2021) A photographic dataset of the beetle specimens from a SITE100 standardized sampling area in Huaping, Guangxi. Biodiversity Science, 29, 1165-1169. doi: 10.17520/biods.2021212.

收稿日期: 2021-05-24; 接受日期: 2021-08-08

基金项目: 国家科技基础资源调查专项(2019FY100400)、国家自然科学基金(31961143002; 31900317)、中国科学院国际合作局“一带一路”项目和广东 省科学院建设国内一流研究机构行动专项资金(2020GDASYL-20200102021; 2020GDASYL-20200301003)

* 共同通讯作者 Co-authors for correspondence. E-mail: wangguoquan0@163.com; baim@ioz.ac.cn 


\section{A photographic dataset of the beetle specimens from a SITE100 standardized sampling area in Huaping, Guangxi}

Panpan Li ${ }^{\mathbb{1} 1}$, Yijie Tong ${ }^{2,3}$, Haoyu Cao ${ }^{1}$, Guosen Rong ${ }^{1}$, Shiqing Qin $^{1}$, Xingke Yang ${ }^{2,4}$, Guoquan Wang ${ }^{(1 *}$, Ming $\mathrm{Bai}^{\left(\mathrm{D} 2,3^{*}\right.}$

1 National Demonstration Center for Experimental Plant Science Education, College of Agriculture, Guangxi University, Nanning 530004

2 Key Laboratory of Zoological Systematics and Evolution, Institute of Zoology, Chinese Academy of Sciences, Beijing 100101

3 University of Chinese Academy of Sciences, Beijing 100049

4 Guangdong Key Laboratory of Animal Conservation and Resource Utilization, Guangdong Public Laboratory of Wild Animal Conservation and Utilization, Institute of Zoology, Guangdong Academy of Sciences, Guangzhou 510260

\section{ABSTRACT}

It is important to quantitatively assess the relationship between insect diversity and the environment by laying long-term sample plots at a global scale. Consequently, the SITE100 International Science Project was proposed. The project plans to select 100 large sites around the world and use three types of data collection methods, namely, flight interception trap (FIT), Malaise trap (MT), and pitfall trap (PT). The global insect diversity pattern is explored from three dimensions: species diversity, morphological diversity and genetic diversity. Huaping, Guangxi was selected as one of the 100 sites to explore the origin of global insect diversity and its relationship with the environment through long-term monitoring and cross-regional large-scale comparison. In this study, the data set of beetles collected from the Huaping site during 2020 growing season lasted 7 months (2020.05.09-2020.11.23), covering 10 sites. Each site contained one FIT, one MT and 10 PT. All sites were visited once a week on average. A total of 8,914 beetles were collected during the study period. 563 morphological species from 57 families were identified. The data set consists of four parts. The first part is the original photos of all beetle specimens obtained from all traps at various collection points, with a total of 644 photos. After compression, the file name is Photo-1.zip. The second part is the photos of beetles grouped by morphological species. After compression, the file name is Photo-2.zip. The third part is the statistics of each beetle specimen: the collection method, and the longitude, latitude, and altitude of its sampling point. The file name for this data set is data-1.zip. The fourth part is detailed identification information of the morphological species of each specimen. The file name is data-2.zip. In addition to joint analysis with the results from other SITE100 sites, this data set can also be used to analyze and compare the distribution and morphological differences of beetle taxa in different habitats. The images of some taxa can provide data support for subsequent geometric morphometrics or morphological studies. This dataset is the first quantitative assessment of beetle diversity in Huaping, and is of great significance in enriching biodiversity background data in China and understanding the origin of insect fauna in southern China.

Key words: morphological diversity; passive collecting; flight interception trap; Malaise trap; pitfall trap

\section{Database/Dataset Profile}

\begin{tabular}{|c|c|}
\hline Title & A photographic dataset of the beetle specimens from a SITE100 standardized sampling area in Huaping, Guangxi \\
\hline Authors & Panpan Li, Yijie Tong, Haoyu Cao, Guosen Rong, Shiqing Qin, Xingke Yang, Guoquan Wang, Ming Bai \\
\hline Corresponding authors & Guoquan Wang (wangguoquan0@163.com), Ming Bai (baim@ioz.ac.cn) \\
\hline Time range & 2020.05.09-2020.11.23 \\
\hline Geographical scope & Huaping, $109^{\circ} 47^{\prime} 07^{\prime \prime}-109^{\circ} 58^{\prime} 10^{\prime \prime} \mathrm{E}, 2^{\circ} 28^{\prime} 55^{\prime \prime}-25^{\circ} 39^{\prime} 15^{\prime \prime} \mathrm{N}$ \\
\hline File size & 6.32GB \\
\hline Data format & *.zip \\
\hline Data link & $\begin{array}{l}\text { https://www.scidb.cn/s/VVveuq } \\
\text { http://doi.org/10.11922/sciencedb.00061 } \\
\text { https://www.biodiversity-science.net/fileup/1005-0094/DATA/2021212.zip }\end{array}$ \\
\hline $\begin{array}{l}\text { Database/Dataset } \\
\text { composition }\end{array}$ & $\begin{array}{l}\text { The dataset consists of four parts. The first part is the original photos of all beetle specimens obtained from all traps at } \\
\text { various collection points, with a total of } 644 \text { photos. After compression, the file name is 照片-1.zip. The second part is } \\
\text { the photos of beetles grouped by morphological species. After compression, the file name is 照片-2.zip. The third part is } \\
\text { the statistics of each beetle specimen: the collection method, and the longitude, latitude, and altitude of its sampling } \\
\text { point. The file name for this dataset is 数据-1.zip. The fourth part is detailed identification information of the } \\
\text { morphological species of each specimen. The file name is 数据-2.zip. }\end{array}$ \\
\hline
\end{tabular}


近些年来, 昆虫多样性的减少引起人们的极大 关注。因此, 通过在全球定点布设长期样地, 定量 评估昆虫多样性与环境之间的关系具有重要意义。 在此背景下, 经中国科学院动物研究所白明与英国 自然历史博物馆Alfried Vogler反复研讨, 最终与诸 多同行共同提出了“SITE100” (Site-based, Insects, Taxonomy, Environment, 100)国际大科学计划(详见 项目网站https://www.site100.org/)。项目计划在全球 选定 100 个大样地(中国至少 10 个大样地), 从物种、 形态和遗传多样性三个维度探究全球昆虫多样性 格局。SITE100项目组选用罐诱法、马氏网法和飞 行阻隔法三类采集装备, 以期获得样地从地表到半 高空的立体化样本收集结果。

广西花坪国家级自然保护区位于广西壮族自 治区桂林市龙胜、临桂两县交界处, 是南岭山地的 一部分。保护区海拔600-1,807.5 m, 属中亚热带气 候, 年均降水量 2,000-2,200 mm, 年均温 $12-14^{\circ} \mathrm{C}$ (汪国海等, 2014; 高海山和许为斌, 2016; 张燕飞, 2019), 区内以常绿阔叶林和亚热带常绿落叶阔叶 林为主。因较高的海拔落差以及湿润的环境, 区域 内动植物资源十分丰富, 生物多样性水平高且具有 极强的稀有性(刘宏和廖德宝, 2014)。目前, 对于该 保护区的研究集中于鸟类和植物, 昆虫多样性本底 不清。为此, SITE100项目组将花坪选为全球100个 大样地之一, 期望通过长期监测和跨区域大尺度比 较, 探讨全球昆虫多样性的起源及与环境间的关系。

本文的数据集为花坪样地 2020 年生长季期间 的鞘翅目收样结果, 历时 7 个月 (2020.05.092020.11.23), 涵盖10个样点。

\section{数据采集和处理方法}

本数据集的构建过程主要包括 4 个方面: 采集 样地的布设、采集方式的设计、样本的收集、数据 的获取及数据库的建立。

\section{1 采集样地布设}

在广西花坪国家级自然保护区 $\left(109^{\circ} 47^{\prime}-\right.$ $109^{\circ} 58^{\prime}$ E, $25^{\circ} 28^{\prime}-25^{\circ} 39^{\prime} \mathrm{N}$ )粗江站, 按照植被类型 丰富、多坡向、海拔梯度丰富、人为干扰较少的原 则布设 10 个样点, 并按1-10依次编号, 其中样点 3 和样点5布设在竹林中, 样点1布设在靠近溪流的位 置。以每个样点中飞行阻隔器设立的地点为标志点, 通过GPS记录每个样点的地理信息(图1A)。

\section{2 昆虫采集方式}

每个样点设置 1 个飞行阻隔器、 1 个马氏网和 10 个埋罐, 设置时遵从以下原则: 飞行阻隔器置于飞 行类昆虫常用的林道上方, 林道要求间距 $2.5 \mathrm{~m}$, 水 槽距离地面 $0.5 \mathrm{~m}$ 且保持水平状态, 避免液体溢出 (图1B) (聂瑞娥等, 2017); 在飞行阻隔器周围布设 马氏网和埋罐, 马氏网网顶距地面 $1 \mathrm{~m}$, 采集地表 及以上 $1 \mathrm{~m}$ 空间的昆虫(图1C); 埋罐两两间隔 $1 \mathrm{~m}$, 呈多条线状设置于靠近水边或林间坡面上落叶层 较厚、小生境较好的地点(图1D)。

飞行阻隔器的水槽内和埋罐所用的采集杯中 放入盐水 $(5 \mathrm{mmol} / \mathrm{L} \mathrm{NaCl})$; 马氏网收集瓶中放入无 水乙醇。采集设备内的溶液于每次收样后更换。

\section{3 昆虫样本的收集}

2020年5月2日于样地架设所有采集设备, 2020 年11月23日完成收样。对飞行阻隔器和埋罐采集到 的昆虫每周收取1次, 对马氏网采集到的昆虫每两 周收取1次, 收样工作在1天内完成。记录采集样点、 方式、时间，同时将收集到的昆虫暂时存放于 $120 \mathrm{~mL}$ 塑料瓶中, 回到营地后统一进行分拣和存 储。飞行阻隔法和罐诱法收集的昆虫样本置于 $75 \%$ 酒精中保存; 马氏网法收集到的昆虫样本置于无水 乙醇(95\%-100\%酒精)中保存。

\section{4 物种多样性数据的获取及数据库的建立}

收集到的昆虫样本带回实验室, 于体视显微 镜(Nikon-SMZ445)下进行鞘翅目昆虫的篮选工 作。使用OLYMPUS 相机(EMIII)配合微距镜头 (OLYMPUS-60 mm) 对甲虫样本进行拍摄记录, 部 分样本由手机(小米8)后置摄像头进行辅助拍摄。具 体拍摄方法: 对每个收样日期内单个样点、单个采 集方式收集到的全部甲虫进行合影, 在甲虫样本量 较多的情况下可拍摄多张照片。拍摄时, 尽量使甲 虫的背部朝上, 同时在甲虫样本旁摆放比例尺, 便 于统计样本的体型(图2)。依据采集标签及采集设备 中记录的相关采集信息对甲虫照片进行命名, 照片 命名的方式为: 2020HPCJ-采集方式+样点编号-收 样时间，1张以上照片命名方式: 2020HPCJ-采集方 式+样点编号(X)-收样时间, 其中HPCJ为本次采集 工作的样地代码(花坪粗江的简称)。这些集体照的 汇总为本数据集的第一部分: 照片1.zip, 代表图详 见图2A-C。依据标本和照片, 将2020年度收集到的 甲虫标本划分为 563 个形态种, 并对这些形态种进 

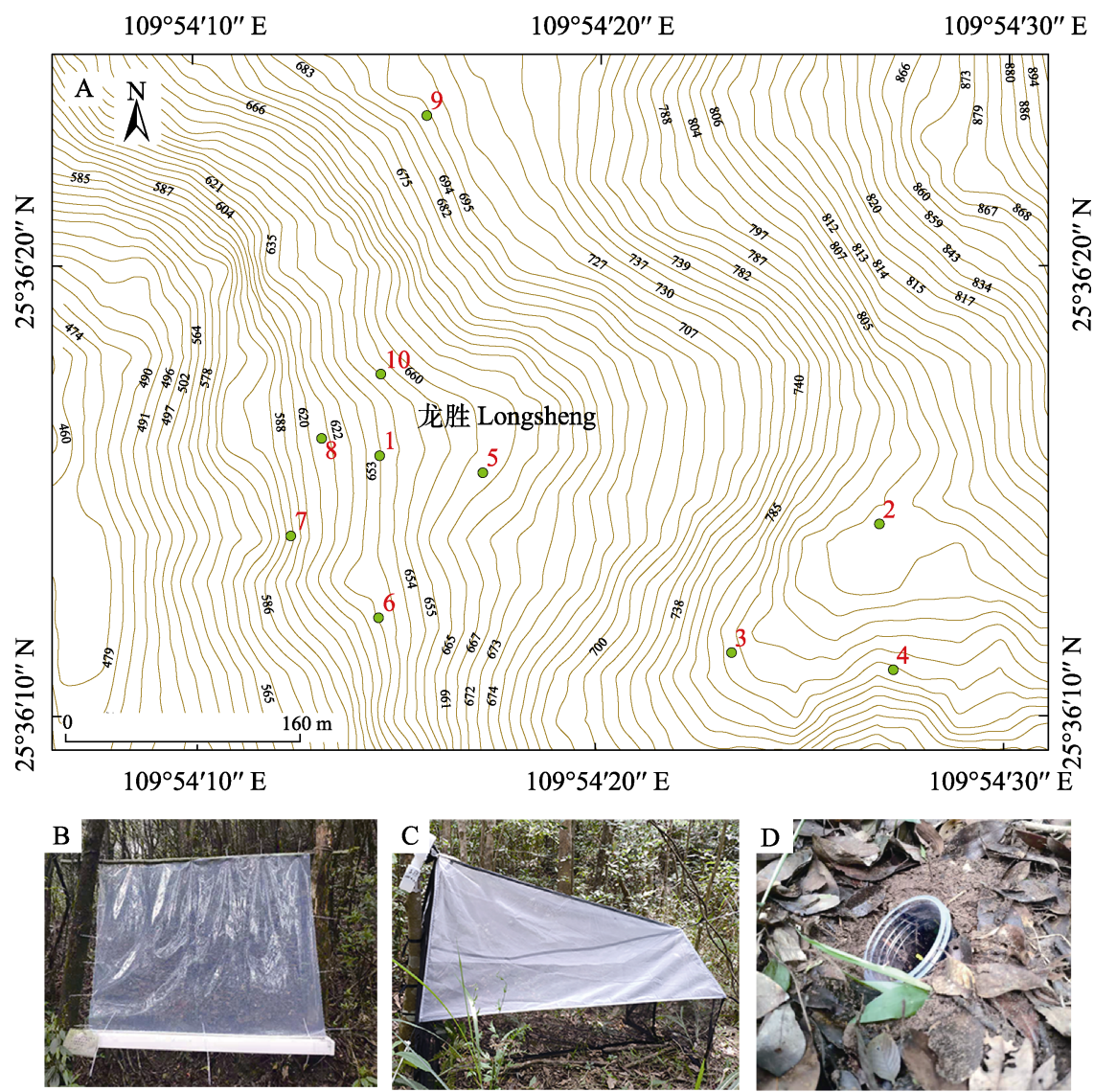

图1 广西花坪国家级自然保护区样地中采集样点的分布情况及采集方式展示图。A：采集样点分布情况; B: 飞行阻隔器; C: 马氏网; D: 埋罐。

Fig. 1 The distribution of sampling points in Guangxi Huaping National Nature Reserve and collection methods showing. A, The distribution of sampling points; B, Flight interception trap; C, Malaise trap; D, Pitfall trap.
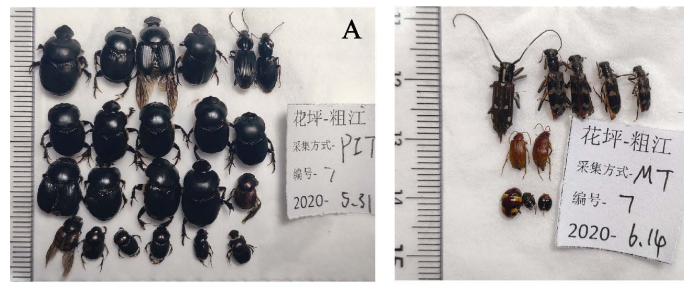

B
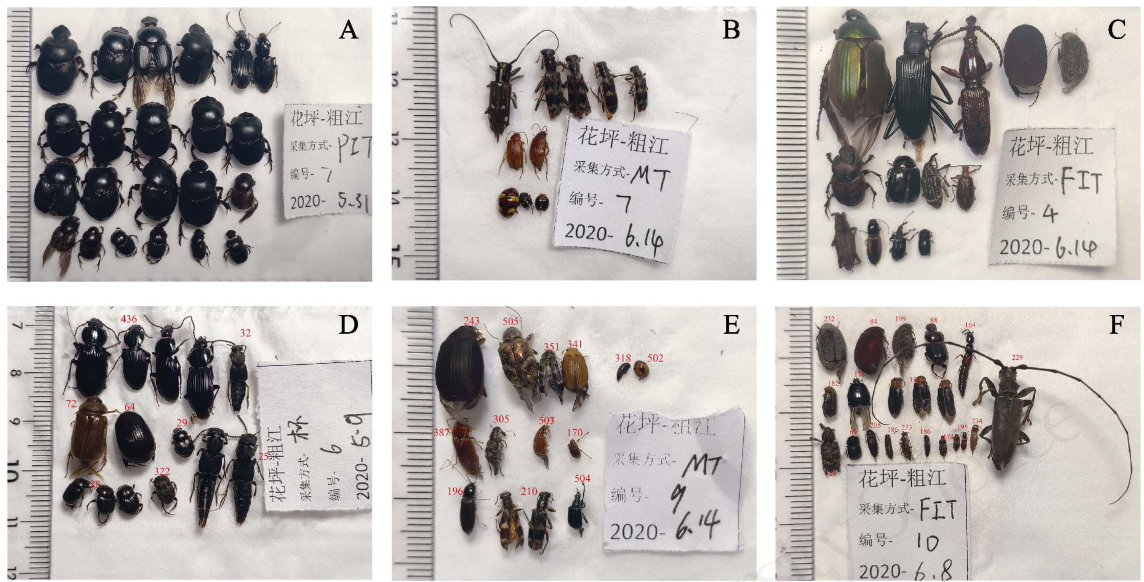

图2 广西花坪国家级自然保护区样地甲虫照片数据集示例。A-C: 三种采集方式采集甲虫标本集体照; D-F: 标注形态种编 号的甲虫标本集体照。

Fig. 2 Samples of the beetles’ photographic dataset from Guangxi Huaping National Nature Reserve. A-C, A group photo of beetle specimens collected by three methods; D-F, A group photo of a beetle specimen labeled with morphological species number.

行编号。利用Photoshop在每张甲虫集体照中标注上 形态种编号, 这些具有编号的标本照片为本数据集
的第二部分：照片2.zip，代表图详见图2D-F。

本文的数据集为花坪样地 2020 年生长季期间 
的鞘翅目收样结果, 历时 7 个月 (2020.05.092020.11.23), 涵盖10个样点的29次收样, 获得8,914 头甲虫。由于每个样地 10 个埋罐距离较近且标本较 少, 故每个样点每次收样所获得的 10 个埋罐的标本 放在同一张集体照中。基于甲虫样本背面观图片建 立数据库, 根据照片对甲虫个体数进行统计。为避 免人为误差, 采用两人一组人工计数的方法分别对 每个收样日期内不同样点、不同采集方式所获得的 甲虫的数量进行统计, 同时将相应样点的经纬度、 海拔与上述采集信息相匹配。最后将收集到的所有 数据录入Excel中进行整理、保存。这些数据为本数 据集的第三部分: 数据1.zip。依据标本和照片, 将 所有形态种鉴定到科级或亚科级(其中金龟科甲虫 鉴定到亚科级), 形态种统计及鉴定信息汇总为本 数据集的第四部分: 数据2.zip。

\section{数据描述}

数据集包括四部分, 第一部分为各样点每个装 备每次收样所获得甲虫标本的集体照原图, 共计 644张, 压缩后为照片1.zip; 第二部分为标注了形 态种编号的甲虫标本的集体照, 共计 644 张, 压缩 后为照片 2.zip; 第三部分为甲虫标本数量统计数据, 涵盖2020年5月2日至11月23日期间3种采集方式各 日期采集甲虫的数量、采集样点的经纬度以及海拔 信息, 共 2 个文件, 压缩后为数据1.zip; 第四部分为 甲虫标本高级阶元(科级或亚科级)鉴定信息, 共计2 个文件, 压缩后为数据2.zip。

\section{3 数据使用方法和建议}

本数据集为广西花坪国家级自然保护区的昆 虫多样性调查提供了数据基础, 同时多种采集方式 融合的取样手段也为其他生物多样性研究提供了 新的思路; 3 种被动采集方式的采集效果为不同采 集方法在昆虫多样性调查的比较分析提供了数据 支撑; 数据集也可用来分析比较不同环境中的甲虫 的类群分布和形态差异, 部分类群的背面观图片为 后续的几何形态学或者形态学研究提供数据支持。

致谢: 感谢广东省科学院动物研究所李志强和杨海 东、湖南农业大学黄国华、广西师范大学陈志林、 南宁师范大学谭梦超等老师在野外工作方面的支
持和指导，感谢广西花坪国家级自然保护区管理处 及花坪保护站工作人员谭周荣在样本采集工作中 给予大力支持, 感谢广西大学农学院杨娟老师在实 验过程中提供便利以及孙麓清、李泓毅、陆莹、雷 文卓、刘炫同学在样本统计工作中提供的帮助。

\section{作者分工}

李盼盼负责数据库的管理及文稿的撰写; 佟一杰对文 稿写作进行指导; 曹浩宇统计及录入标本数据; 容国森和覃 诗晴采集昆虫标本并统计相关数据; 杨星科审阅文稿; 王国 全统筹管理保护区样地; 白明进行本研究的设计、数据库框 架的设立以及文稿的改进。

\section{ORCID}

李盼盼 (D) https://orcid.org/0000-0002-4292-6624

王国全 (D) https://orcid.org/0000-0003-1693-1654

白明 (D) https://orcid.org/0000-0001-9197-5900

\section{参考文献}

Gao HS, Xu WB (2016) Wild plants resources of Huaping Nature Reserve in Guangxi. Horticulture \& Seed, (4), 35-37. (in Chinese with English abstract) [高海山, 许为斌 (2016) 广西花坪国家级自然保护区野生植物资源. 园艺 与种苗, (4), 35-37.]

Liu H, Liao DB (2014) Exploration of biodiversity conservation strategies in Guilin Huaping Nature Reserve. Industrial \& Science Tribune, 13, 214-215. (in Chinese) [刘 宏, 廖德宝 (2014) 桂林花坪自然保护区生物多样性的 保护对策探索. 产业与科技论坛, 13, 214-215.]

Nie RE, Yang MX, Xue HJ, Yang YR, Tong YJ, Qiu TF, Bai M, Yang XK (2017) The application and effectiveness of a flight interception trap for insect collecting. Chinese Journal of Applied Entomology, 54, 530-535. (in Chinese with English abstract) [聂瑞娥, 杨美霞, 薛怀君, 杨御儒, 佟一 杰, 邱腾飞, 白明, 杨星科 (2017) 飞行阻隔器在昆虫采 集中的应用探究. 应用昆虫学报, 54, 530-535.]

Wang GH, Shi ZP, Liu XJ, Zhou QH, Xiao ZS (2014) Camera trap survey of mammals and birds in Huaping National Nature Reserve, Guangxi. Biodiversity Science, 22, 785-787. (in Chinese) [汪国海, 施泽攀, 刘秀菊, 周岐海, 肖治术 (2014) 花坪保护区鸟兽物种的红外相机初步监 测. 生物多样性, 22, 785-787.]

Zhang YF (2019) Bird resource and diversity analysis in Huaping National Nature Reserve of Guangxi. Journal of Anhui Agricultural Sciences, 47(20), 97-102. (in Chinese with English abstract) [张燕飞 (2019) 广西花坪国家级自 然保护区鸟类资源与多样性分析. 安徽农业科学, 47(20), 97-102.]

(责任编委: 黄晓磊 责任编辑: 间文杰) 